\title{
Real estate dynamics in neighborhoods adjacent to downtown Porto Alegre, state of Rio Grande do Sul
}

\author{
Dinâmica imobiliária da habitação em bairros \\ adjacentes ao centro de Porto Alegre/RS
}

Nicole Leal de Almeida [I] Heleniza Ávila Campos [II]

\begin{abstract}
Urban transformations resulting from the housing financialization process have influenced the spatial dynamics of Brazilian metropolises. Since then, sectors of large Brazilian cities with land that can be used for developing new real estate products or susceptible to urban upgrading projects have become the target of intensive actions by real estate developers. Investments in infrastructure that have integrated the State's social interest projects into areas unattractive to real estate capital have contributed to similar actions. The article aims to discuss the action of the real estate sector in the IV District of Porto Alegre between 2007 and 2016 by understanding the effects of real estate arrangements on housing space and on the current attempt to re--signify this sector.
\end{abstract}

Keywords: neighborhoods adjacent to the downtown area; financialization; real estate sector dynamics; urban restructuring.

\section{Resumo}

As transformações urbanas oriundas do processo de financeirização da habitação influenciaram na dinâmica espacial das metrópoles brasileiras. Desde então, setores das grandes cidades brasileiras com terras passíveis de incorporação de novos produtos imobiliários ou suscetiveis a projetos de requalificação urbana tornaram-se alvo de ações intensivas por parte de incorporadoras imobiliárias. Contribuíram para ações similares os investimentos em infraestrutura que integraram os projetos de interesse social, por parte do Estado, em áreas pouco atraentes ao capital imobiliário. Este artigo tem como objetivo discutir a atuação do setor imobiliário no IV Distrito de Porto Alegre, entre 2007 e 2016, através da compreensão dos efeitos dos arranjos imobiliários no espaço de moradia e na tentativa vigente de ressignificar esse setor.

Palavras-chave: bairros adjacentes ao centro; financeirização; dinâmica do setor imobiliário; reestruturação urbana. 


\section{Introduction}

The transformation of housing into a commodity and financial asset is not the result of a recent dynamic, since the construction of homeownership culture permeates a significant part of Brazilian housing policies. However, in its contemporary version, homeownership culture gained strength through the expansion of housing credit and securitization, which enabled the entry of middle and low-income classes on the market. Thus, a real social issue is highlighted - the lack of decent housing for the low-income population - to respond to capitalist interests. This took place in a global context of "housing financialization" and the takeover of residential development by the financial market. In addition, in Brazil, the incentive to produce and purchase durable goods through exemptions and subsidies made workers and small business owners figure as the "new middle-class". A social stratum that helped build a large part of the demands corresponding to the private housing market expansion (Rolnik, 2015; Fix, 2011).

In this context, changes in the real estate market, especially its connection to the financialization mechanisms of the housing sector, through credit granting and exemptions that expanded the possibility of funding, caused the demand by the real state market for land to increase considerably. Historically, Brazilian housing policy is marked by mechanisms that favor certain actors involved in the production of urban and metropolitan space, especially the private market activity. The origins of confluences between the state and the private real estate market arise, more evidently, since the 1990s, with the influence of neoliberal practices of political economy in the country (Rolnik, 2015), and are enhanced by housing programs structured in subsequent governments, particularly the Lula governments (2003-2010).

With the expansion of the real estate market areas of activity, particularly since 2007 and 2008, ${ }^{1}$ in Brazil, some city sectors have become objects of speculation, notably, areas of potential value. Considering the market is one of the main housing developers, the offer - at any time - will be prioritized in areas of the city which these agents deem profitable (Cardoso e Aragão, 2011). Thereby, we highlight, here, the interests of the real estate market regarding areas adjacent to downtown, which have undergone a process of deindustrialization and degradation of its built environment.

Unlike areas where the land is cheap due to lack of urban infrastructure, but are distant from the commercial and historical center, the areas adjacent to downtown undergo a process of devaluation of their built heritage, by the divergence between the current forms of use and their land occupation. And, generally, these areas are associated with underserved communities with low bargaining capacity over their territory, while urban growth is stimulated in other sectors of the city. Singer (2017) points out that an existing strategy to contain the deterioration of these city sectors is the state intervention, through expropriation and renewal programs. However, such actions, which lean towards the valuation of the area, end up jeopardizing longtime residents, whereas large construction companies and developers, with the ability to anticipate the valuation by acquiring lots, tend to achieve profitable results on the sale of real state after the improvements. 
Therefore, this article intends to discuss the participation of large real estate development companies in areas near downtown, which are identified by the market and the state as decaying and marginalized areas, and by the tension between the strata of its most vulnerable and impoverished resident population. The area adjacent to downtown Porto Alegre/RS, known as the IV District, was used as an object of analysis. It is composed of the neighborhoods Floresta, São Geraldo, Navegantes, Farrapos, and Humaitá. The area of study in question was crucial for the socio-spatial development of Porto Alegre, given its strategic location regarding the main accesses to the city and proximity to the historic center, which influenced its occupation by the industrial park in the early 20th century. Nevertheless, the area underwent an obsolescence and degradation process and became the object of economic conversion and restructuring through the potential of real estate and financial capital participation.

It is possible to assume that, from investments in infrastructure and large-scale construction projects promoted by the Porto Alegre City Government (PMPA), the real estate market identified in the area the possibility of adding value to land and implementing new real estate products. Thus, low-income local residents who occupied spaces hitherto obsolete from an economic and functional point of view find themselves under physical and legal pressure, either through repossession actions or eviction or by the increasing demands of the real estate market for new constructions. From these analyses, we intend to contribute towards understanding the actions of large companies in neighborhoods adjacent to downtown and how, in the current context of the housing finance crisis, companies seek to maintain the productive restructuring standards of these territories.

The article structure consists of four parts, besides the introduction and final considerations. The first part aims at the characterization of the area adjacent to downtown and explains how it is attractive to the real estate market. The second presents the historical background of the characterization of the area under study. In this part, we intend to identify the processes of consolidation (from its creation until the 1970s), obsolescence (from the 1970s onwards), and degradation of the area (between the 1970s and 1990s), that is, the processes that preceded the real estate logic restructuring of the area. The third part aims to present how, from 2007 onwards, the incentive to the real state market entry in the territory took place. Then, in the fourth part, an analysis is presented on the distribution of real estate products in the IV District area and its direct consequences to the local population, with a special focus on the current investment movements and the construction of new developments by the real estate market.

\section{Obsolescence and degradation in areas adjacent to downtown}

Studies concerning the internal structures of the city recurrently need revisions and rereadings as a result of the continuous transformations and resignifications the spaces assume over time. The importance of the 
central area and areas adjacent to it persists in Brazilian cities, with issues that need to be considered, such as spatial processes of obsolescence and functional and economic redevelopment. Indeed, the areas adjacent to downtown are attractive to the real estate market due to their constructive potential, the existence of infrastructure, and their privileged location for new developments installation. It should be noted that, although studies about the internal structure of the city based on spatial patterns are not recent, it is necessary to discuss them to understand the development of certain sectors in the city, in this case, in particular, the area adjacent to downtown.

The area adjacent to downtown is understood by some authors as a transition zone between the commercial center and the zone of more residential predominance. Since the 1920s, researchers have developed models and studies which show that urban land uses are not randomly distributed. Burgess, according to Strohaecker (1988), classified the areas in question as transition zones. They are characterized by mixed-use, with industries, businesses, and residences. The residential use, in turn, is reduced and ends up being appropriated by low-income people and vulnerable groups. The study model by Burgess believes that, due to its proximity to downtown, this zone becomes attractive to businesses and services and that it would, eventually, absorb the surpluses of the central area.

Strohaecker (1988), however, points out that the central zone decentralization and verticality thwarted Burgess' expectations that the transition zone would be "invaded" by businesses and services, given its proximity to the central area. What was observed, contrary to what Burgess believed, was the difficulty of adapting the physical structures, resulting in issues regarding their aging. Those are the areas that have a social and economical structure liable to slower transformations, in general, promoted by intermittent movements of lack of interest and investment of the urban real estate market that result in successive socio-spatial processes of degradation and revaluation, typical of capitalist cities. Thereby, Strohaecker (ibid.) notes the "crystallized" profile of the structures in the hitherto socalled "transition zones", renders the use of the term "transition" inadequate. The author also remarks that more recent studies indicate the term "zone peripheral to" downtown prevails over the concepts "transition", "grey area", or "zone of obsolescence", by not labeling rigidly, but rather absorbing its characteristics. However, considering the discussions and different meanings of the term "periphery", we chose to use the term areas adjacent to downtown in this article.

In general, the neighborhoods adjacent to downtown constitute an area of semiintensive use, which encompasses wholesale trade activities, former industrial districts with vacant land, and very particular morphological characteristics, according to Corrêa (1989). Still based on the author, among these characteristics, regarding the industrial use, is the recurrent abandonment of structures and buildings when companies are no longer benefited by the location and are faced with limited possibilities for industrial plants expansion. When it comes to residential use, on the one hand, the author notes the sector is characterized by popular and lower-middleclass residences; on the other, he points out the area is the main focus of urban renewal 
policy, which consists of replacing decaying buildings with new apartment buildings, resulting in the replacement of poor residents by the middle-class.

The characteristic pointed out by Corrêa (ibid.), of replacement of older buildings and also of more traditional residents, requires some time to develop in the urban space, thus causing a long period of social, functional, and economic depletion of the sector, in which its obsolescence and degradation manifest. The crystallization of structures requires the development of policies and strategies, along with investments on the part of the state usually represented by the local government to arouse the interest of the real estate market. For Singer (2017), the devaluation of the area adjacent to downtown and, consequently, the reduction of land value can also encourage the neglect by owners of older buildings at times when there is no interest from the real estate market, the state, and other investors for urban renewal or redevelopment. For these transformative processes to take place, it is necessary a condition in which these social agents feel motivated, the state, in general, being the articulator of actions that promote the necessary conditions for the area to be attractive again. The author also states urban renewal programs often recover the deteriorating areas for the use of the middle and rich classes and the companies that provide them services.

In this sense, by observing the realities of areas adjacent to downtown in large Brazilian cities, it can be seen that certain transformations, both in the financial structure of the real estate sector and the public housing policies, were crucial to enable urban restructuring projects. Shimbo (2010) highlights that, in a recent context (20052010), the financial market drew closer to the real estate sector in Brazil. Thereby, businesses that were previously family-owned opened up to the financial market and began to render available shares in the national and international market. This leveraged the initial public offering of companies in the stock market, which prompted the process of real estate financialization. The rapprochement between the financial and real estate markets was guided by a set of measures by the federal government over the past 10 years, allowing more legal security for developers, builders, and investors, while regulatory measures stimulated the housing production via the market, according to Shimbo (ibid.).

Announced in 2009, the package My House My Life (Minha Casa Minha Vida) played a definitive role in solidifying the transformations in the real estate market and urban landscape of cities, since it had as one of its objectives to minimize the results of the 2008 financial crisis (Fix, 2011). Furthermore, Shimbo (2010) points out the program intended to "attack" two demands: generate work through civil construction and attend to the low-income housing. To Fix (2011), the program, developed under the leadership of the Executive Office and the Ministry of Finance, articulated a national priority problem through the real estate capital criteria. In this sense, still based on Fix (ibid.), many companies have indicated the MCMV (My House My Life) as the inductor for their market expansion. As an example, the author presents data relating to the Rossi company, which increased from $29 \%$ to $48 \%$ its total number 
of launches in 2009, comprising a class that until then had no access to homeownership. The launch line of the economic segment has a variant definition, but its products usually have up to $85 \mathrm{~m}^{2}\left(914 \mathrm{ft}^{2}\right)$.

It is in this context that the spatial cutout analyzed in this article is inserted. To better understand the general aspects that permeate the transformations of the IV of District of Porto Alegre, it is important to comprehend how the territory consolidation and the process of underutilization of the area that preceded the restructuring took place, from the real estate logic presented so far. Thus, the next part aims to present an overview of the history of this city sector.

\section{Characterization and configuration of the real estate logic in the IV District}

The IV District history presents spatial processes characteristic of an area adjacent to the central area. The consolidation of the former industrial district of Porto Alegre/RS and its surroundings takes place through the favorable and strategic conditions in which the city is inserted regarding the logic of expansion prevailing in the 18th and 19th centuries. Both the proximity to the Jacuí Delta, north of the Patos Lagoon, and its location at the entrance of the city, on the Guaíba banks, favored the waterway transport of the production exported from this region, as well as, subsequently, the use of railway line (Singer, 1977).

Souza and Müller (1997) reaffirm the industrial cycle of Porto Alegre occurred from the mid 19th century onwards, simultaneously with the city expansion through its main access routes, the main one being the then Caminho Novo (later named Voluntários da Pátria street). This route connected the industrial neighborhood Navegantes, located near the commercial center of Porto Alegre, to the newly established São Leopoldo Colony, in 1824. An area previously occupied by indigenous people Kaingang and Carijós, which was assigned to the German immigrants by the Brazilian imperial government, with the intention of occupation and expansion of its territory.

In this sense, in addition to the location near the main structural axis of the city, which facilitated access to the center and was also a passage for travelers, its physicalnatural characteristics (proximity to large waterways and flat topography), suitable for industrial occupation, stand out. As a result, not only the Caminho Novo was consolidated, but also part of what is now known as the neighborhoods Floresta, São Geraldo, and Navegantes, ${ }^{2}$ identified as the industrial sector of the city (Fernandes, 2014; Souza and Müller, 1997). Figure 1 highlights, in darker grey, the location of these neighborhoods.

With the expansion of industrial facilities and the increasing European migration flow, the city of Porto Alegre presented a great demographic growth between 1872 and 1890, which resulted in a shortage of public housing that met the market demands. In this context, in 1892, the Territorial Company of Porto Alegre (Companhia Territorial Porto Alegrense) was founded, being responsible for the land division of the city, working mainly in its northern zone, more specifically in the neighborhoods Navegantes, São Geraldo, 
Figure 1 - Location map of the IV District - 2021

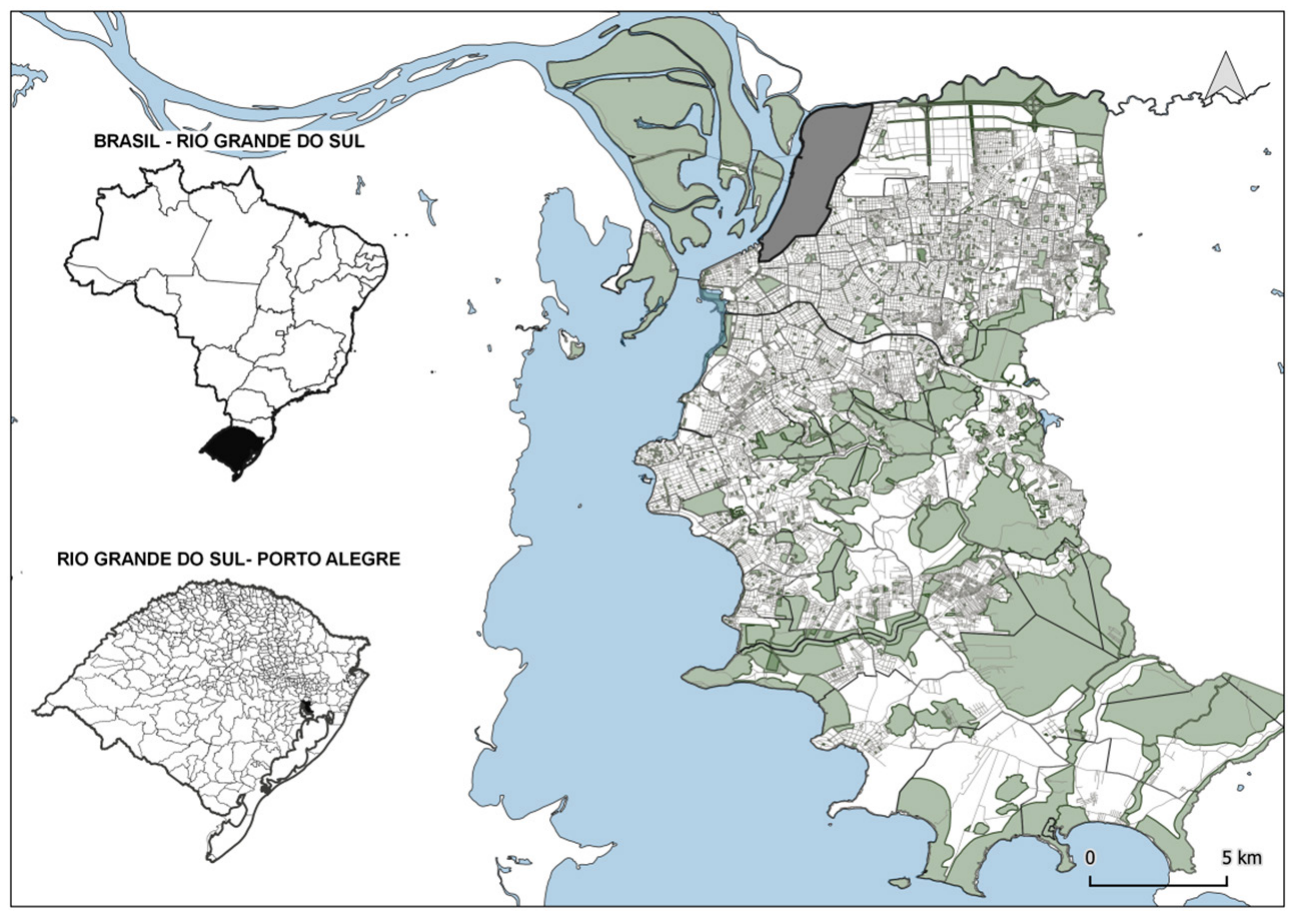

Prepared by Nicole Leal de Almeida, in 2021.

and part of the São João and Higienópolis neighborhoods. The Navegantes and São Geraldo neighborhoods, being established side by side in a region of lower topographic elevations, flood-prone and farther from downtown, were assigned to the immigrants who were seeking to settle in the vicinity of factories located in the region (Souza and Müller, 1997; Strohaecker, 2005).

Therefore, this social and economic scenario constituted the region, with a more reticulated urban layout, articulating large factory buildings and industrial warehouses to the occupations of residential use, mainly aimed at workers and immigrants, until approximately 1940. The great flood of 1941, which caused flash floods and damage to the city, was the first stimulus to the relocation of industries to locations farther away from the waters and close to the road axes. The impacts caused by the flood mark the beginning of the area decay process, since many buildings and industrial warehouses were put out of action and abandoned (Titton, 2012). Moreover, the association of low and flood-prone areas with rejected activities caused the sector to become increasingly less attractive to the real estate market (Mattar, 2010). 
The changes resulting from the growth of Porto Alegre were also transforming the IV District occupation. Successive embankments on the Guaíba banks, as well as the completion of the Cais do Porto [Porto Quay (1911-1962)], important works for water containment and flood protection, eventually isolated the city from the Guaíba River. Other important works, such as the construction of the Farrapos avenue (1940) and the intersection of the streets Voluntários da Pátria and Conceição, also contributed to the seclusion of this part of the city (Mattar, 2010; Titton, 2012).

In terms of urban legislation, the first Porto Alegre Master Plan (Law No. 2046/1959, with an amendment to Law No. 2330/1961) sought to contain the verticalization and the exclusive industrial use of the area, allocated to a large part of the neighborhoods Floresta, Navegantes, and São Geraldo, which also contributed to its depletion. This direction was maintained in the 1979 Urban Development Master Plan (PDDU) (Titton, 2012). In an opposite direction, the state government of Rio Grande do Sul focused on the structuring of an industrial decentralization policy. That is, a process of relocation of industrial plants, driven by population agglomeration and the metropolization in the 1970s.

As a result of this decentralization, industrial districts were established along the BR-290 (East-West direction), removing them from the IV District region, which was already entirely inserted in the urban fabric. Projects of industrial allotment in new areas, with the state government incentive, through areas expropriation and ensuring the infrastructure for the functioning of companies, entailed the relocation of many companies and industries from the northern zone of Porto Alegre, that claimed to have no conditions to expand within the limits of the capital (Fernandes, 2014). Therefore, the result of this process was the depletion of the first industrial sector of the city, by not only the industry but also the working class residing in the vicinity of the companies in which they worked. With this, not only the old industrial warehouses and buildings became obsolete, but also trade activities and services closed their doors, as the everyday practice hitherto established gradually lost its characteristic.

Currently, the former industrial district is the subject of several revitalization proposals that differ in terms of the intervention spatial cutout. These proposals tend to two positions: a) disregarding the distinct spatial practices existing in these neighborhoods, imputing to the old district an identity close to the new ways of economic conversion, especially related to the creative and cultural economy; b) dividing the territory of the IV District into three areas: the Floresta and São Geraldo neighborhoods, closer to downtown and middle and uppermiddle-class neighborhoods and, thus, with higher potential to attract investors; the Navegantes neighborhood, considered to be a transition zone with a cultural-religious potential of different basis, the festivities related to the Catholic Church being privileged by the proposals, above all; lastly, the Farrapos and Humaitá neighborhoods, which, despite being predominantly residential, have striking differences between them. Thereby, what is presented in the sector is the configuration of different spaces and ways of appropriation of its land use, evidenced as we verify distinct spatial practices, by both hegemonic and counter-hegemonic agents. 
However, given the complexity of the existing spatial practices in the IV District, the efforts of this research were focused on the analysis of the real estate market dynamics. The emphasis is given to the period between 2007 and 2016, which reverberates in the recent propositions. These, on their part, are based on image-making strategies-in the terms of Arantes (2013)-, especially in the neighborhoods closest to the central area, that is, Floresta and São Geraldo. In the Farrapos neighborhood, the occupation of vulnerable families predominates. These families have a high degree of legal tension with the municipal government over their stay in the place. In Humaitá, subject of intensive action by real estate companies, the production of housing for the middle-income segment stands out. The first IV District restructuring initiatives, under the supervision of the Porto Alegre city government coordinated with the real estate capital interests, will be discussed in the following part.

\section{First urban restructuring initiatives of the area}

Given the context of the functional decline of the area adjacent to downtown, in the sociospatial development process of the city of Porto Alegre, now we must seek to understand how the first attempts to transform this sector of the city through the resignification of its spaces took place. As the sector under analysis presents extensive urban infrastructure, besides a privileged location - the main characteristic that adds value to urban land - we start from the attempt to reintegrate the IV District in the economic cycle of Porto Alegre in the mid-1990s.

The restructuring of the territory has not only local (city of Porto Alegre) but also metropolitan and regional importance, linked to the needs and coordination conditions of the city with the global economic market. This is due to the various transport modes that circulate near or within the sector. In addition to the proximity to important logistics equipment, such as the port region, the Salgado Filho International Airport, and the Trensurb metropolitan train, the area also has important connections through easy access to the main highways in and out of the capital. However, despite the potential related to location, accessibility, and infrastructure, it is observed that the wearing and obsolescence of the uses and buildings have always hindered real estate businesses of the glebes and abandoned land of the sector. In this regard, restructuring projects of its functions and uses have been developed.

From the national scenario point of view, according to Rolnik, Cymbalista, and Nakano (2011), it is important to emphasize that, despite the recognition of the social function of property by the 1988 Constitution, in the real estate sector and the construction of housing policies in the country, the decades of 1980s and 1990s were periods of lack of investments. This occurred due to limited resources directed to housing production and the public debt, in addition to the suspension of the BNH [National Housing Bank (19761986)], which culminated in a period of downturn in real estate activity and housing finance. This scenario begins to change from 
the mid-1990s onwards, when, besides the urban entrepreneurship, under the neoliberal perspective as a response to the economic and political crisis, reforms were carried out in the housing credit regulation model regarding the capital structure of companies involved in the real estate market (Rolnik, 2015).

During the Fernando Henrique Cardoso government (1995-2002), there was the installation of the Real Estate Financing System, which raised resources in the real estate market and had, as its main difference from the previous systems, the end-user credit. In turn, in 1997, in Porto Alegre, the 1st Municipal Housing Conference was held, which aimed at the integration of housing production with access policies and popular participation.

However, housing issues were not a priority in the agendas of the city government, which dealt with the restructuring of neighborhoods adjacent to downtown Porto Alegre during the 1990s. With the end of the $\mathrm{BNH}$, the fund-raising for the construction of social interest housing in the metropolis occurred, between 1990 and 2000, through the Habitar Brasil/BID program and the Financial Fund for the Development of the River Plate Basin (Fonplata). Through those resources, the City Entrance Integrated Program (PIEC) was implemented, it attended the Humaitá/ Navegantes region with housing and infrastructure works. However, it was only in 2005 that the program received the necessary impetus to be implemented. The actions developed at that moment sought to minimize the years of restriction of primarily industrial zoning use and aimed at urban regeneration.

Among actions that sought the economic conversion is the Urban Technology Park (PTU) project, which began in 1995 and aimed at transforming, in particular, the former IV District space into a technology innovation center. The reasons that led to the choice of the area were the concentration of companies from the electronic and high-tech niche and the presence of idle and low-cost areas, other than the locational advantages already mentioned. Titton (2012) states the definition of the IV District as the ideal location for the PTU installation occurred after consultancy with the Spanish architect Josep Maria Llop Tomé and the economist Rafael Gonzalez Tormo, director of the 22@Barcelona project. The goal was to transform the area into an urban corridor, delimited by the Sertório, Farrapos, and Castelo Branco avenues. Nevertheless, the program ended up being discontinued upon difficulties encountered concerning the agility and origin of the necessary investments and had its activities shut down definitively in 2005 with the change of the city government ${ }^{3}$ (ibid.).

In the following years, other actions were developed in an attempt to stimulate the area. Between 1998 and 2000, studies were carried out for the drafting of the report "Integrated Projects, Productive Modernization and Technology Innovation: The IV District of Porto Alegre", developed by the Porto Alegre city government. The project had among its pretensions to establish the urban revitalization and economic conversion of the IV District. It concluded that to achieve this, structural changes of basic sanitation, urban mobility, and reversal of the image of the sector would be necessary, through investments in public space that established a new degree of urbanity. The aforementioned report also points to the necessity of valuing cultural heritage and the densification and mixing of land use, with attention to social 
issues, such as the situation of papermakers located in the region and drug enforcement (Albano, 2015).

The already mentioned Piec had its contract signed in 2001 and the works began in 2005. Resources allocated to the program were estimated at $\$ 55$ million and included, in addition to the social interest housing projects, road infrastructure, landscape valuation, and social work (PMPA, 2009). The target population of Piec consisted of 3,775 families of original residents of precarious settlements located in the area of intervention of the project. Thus, 3,061 families received new housing units, 416 had their lots urbanized, and 298 had the infrastructure in their lots complemented (Miron, 2008). Still based on Miron (ibid.), these Social Interest Housing Developments (EHIS) proposed by Piec retained $73 \%$ of permanence in the developments evaluated by the author. Despite the difficulty of identifying the unmet expectations, among the most frequent reasons for the non-permanence are problems of adaptation to the project and payment of the use and occupancy fees of the housing units; problems with the neighborhood; and violence also figures as an evasion influencer. The author also notes part of the adaptation problems of the residents to the implemented project is related to the income generation activity of the families. Many of the included families have as their main source of income the recycling of waste and use horses, drays, and pulling carts, which demonstrates the lack of integration between the housing projects and the work and income generation activities, according to Miron (ibid.).
The key point of transformation in the area has as a mark the definition, in 2007, of Porto Alegre as one of the capitals that would host the 2014 World Cup. With this, some infrastructure and development projects were proposed for the event and to promote the restructuring of the region, with highlight to the Grêmio Arena Foot-Ball Porto-Alegrense, a sports complex inaugurated in 2012 , located near the EHIS implemented by Piec. The Arena project was approved by the regulatory agencies as a project of exceptional character, with the justification that a work of this magnitude would add value to its surroundings and the city as a whole. The project promised, besides the Arena itself, a housing estate of $78,500 \mathrm{~m}^{2}\left(844,974 \mathrm{ft}^{2}\right)$ consisting of seven towers, a business center of $439,000 \mathrm{~m}^{2}$ $\left(4,725,396 \mathrm{ft}^{2}\right)$, a shopping mall, an events center, and a hotel. The seven towers that make up the housing estate are prevented by judicial decisions to receive the certificate of occupancy by the city government. Regarding the commercial projects, as of the date of this research, they had not been concluded.

At that moment there was a change in real estate operations in the vicinity of the Arena and, consequently, in the areas of social interest housing. With the inflow of investments coming from Piec and, in particular, with the added value claim of the Arena works, the area gained speculative potential. To a large extent, the speculation was driven by a narrative of the real estate capital allied to the financial capital, which produced spaces to be consumed as a commodity by a population oblivious to the housing spaces of its surroundings. This was 
made possible by the entry of real estate development companies in the stock market, generating conditions for fund-raising for the construction of projects that would be financed, according to Shimbo (2010).

In addition, Shimbo (ibid., p. 117) notes, between 2004 and 2008, "there was stabilization and growth of the Brazilian economy and increase of the purchasing power of the population," as a result of the increase in the number of "subjects liable to obtain credits a new range of housing demands was opened and could be damped by the real estate market"(our translation). However, it is necessary to emphasize the increase of subjects liable for credit and, consequently, the increase of market demands, does not result in the decrease of seclusion and housing deficit. As the author presents in her research, the rising economic segment, at that time, does not correspond to the housing deficit of the country. The housing deficit corresponds, mostly, to the population with household incomes of up to 3 minimum wages (MW), the population with an income above $5 \mathrm{MW}$ being a small portion of the deficit, yet, it is precisely this portion that is met by the economic segment. This divergence is evidenced when analyzing the average household income of people in situations of vulnerability and those met by the developments of the economic segment surrounding the Arena, as will be seen later.

Regarding the implementation of the Arena complex, the integration between the sports, commercial, and housing towers sectors in the surrounding area, with a large number of families in situations of vulnerability, brings to light the complexity of real estate dynamics. To Rolnik (2015), this rapprochement shows the meeting and conflict points that occur between the real estate/financial sectors and popular territories, deepening the existing contradictions. These contradictions, as Carlos (2015, p. 33) reminds us, clarify that "the clash between what exists and what is imposed as new is at the base of the metropolis' transformations, where places are being integrated successively and simultaneously to a new logic" (our translation). Thereby, for the author, this process represents the violence with which the processes of urban space production are moved in the current model, turning the metropolis into a space in which conflicts are evident.

When it comes to the territory under analysis, the contrast between these sectors has left severe marks: in 2013, a fire of unconfirmed origin destroyed 90 houses, affecting approximately 193 families in the Vila Liberdade slum, near the stadium. These families were sent to transitional housing, built in the molds of "ecological houses", which would have the maximum durability of five years, many of them destroyed by a new fire that happened recently. Other families started receiving social renting in the amount of $\mathrm{R} \$ 500.00$, whose closure promoted the return of the families to the place of origin. Currently, 200 families reside in the Vila Liberdade slum, however, many of them do not have a register in the Municipal Housing Department, and, without register, they are not assured of receiving a housing solution.

Moreover, the works of compensation related to the stadium construction in the area, which should have been carried out in 2012 (and are still pending), had their 
directions once again redefined in December 2020. At the moment, the Public Prosecution Office has entered an agreement with OAS, the company currently responsible for the project, that the company should execute infrastructure improvements in the surroundings of the stadium. Among the improvements are planned: macro-drainage works, which aim to reduce the impact of flooding in neighborhoods of the region, that were aggravated by the implementation of the Arena complex, and the construction of a headquarter for the military police of Rio Grande do Sul (MPRS, 2020).

In this scenario, with the entry of new real estate housing developments focused on the middle-income and linked to recreational and commercial buildings, the necessities of vulnerable families residents of the area were neglected. Making evident the use of housing as an element of economic conversion of the area use and occupation. To Rolnik (2015), supported by Aalbers (2015), this occurs due to the transformation of the very nature and form of action of contemporary capitalism, in which the political economy of housing is led by the "financialization" process. With the culture of homeownership, "credit socialization", and inclusion of middle and lower class consumers in financial channels, the housing sector opened new doors for capital accumulation, allowing "the free movement of values through virtually all urban land" (our translation) (Rolnik, 2015, p. 27). Thus, the current dominance of the financial sector over the industrial production sector coordinates the production of urban space at the global level (Carlos, 2015), placing as the central object of capital accumulation the consumption of new real estate products.
It is worth mentioning, however, that the insertion of housing estates and corporate towers in the region originated, also, from initiatives of the state itself and not only the real estate market. The Urban and Environmental Development Master Plan - PDDUA review, in 2011, had a great influence on the transformation of land use and occupation, with great emphasis on the IV District area. At the time of the PDDUA review, at the request of a part of the local community more involved with the creative economy, the Working Group of the IV District (PMPA, 2008) was created at the Municipal Planning Department (SPM). The Working Group had as its horizon the 2014 World Cup and aimed at developing guidelines and projects that would contribute to the urban space qualification, under the prerogative of sustainable development and better quality of life in the region. Its area of activity included the Bus Station, the Voluntários da Pátria street, considered a structural axis with great renewal potential, going as far as the Humaitá neighborhood, where the Grêmio Arena was located.

The 2011 PDDUA presented significant changes compared to previous plans. One of the most significant changes in the area under analysis was its relation to the division of the city into macro-zones, those that cover the IV District being: the Macro-zone 1 (Radiocentric City), which receives stimulus for land mixing and protection of cultural heritage; and the Macro-zone 2 (Development Corridor), considered strategic for the city polarization, with integration between important equipment of sectors near the IV District, such as the airport and the supply centers (Ceasa). For the area in focus, in the PDDUA, Special 
Areas of Social Interest (AEIS) and Social Interest Housing (HIS) are also defined, which would aim to include self-generated popular settlements in underutilized or empty areas with existing infrastructure. The reduction of social-spatial seclusion sought with the AEIS and HIS not only was not achieved but what is verified, according to a subsequent approach, is the isolation of areas occupied by precarious settlements regarding the areas that developed through the real estate dynamics' logic. Insufficient investments in social interest housing and regularization of the settlements in the area, especially in the Farrapos and Humaitá neighborhoods, created conditions conducive to conflicts and fights for the territory.

With the expansion of real estate development companies and implementation of new developments in the area, the real estate dynamics in the IV District have been considerably transformed, reflecting the variety of social agents inserted in the transformation processes of the territory. The plans and projects that had, until the 1999 PDDUA, the state as the main decisionmaking control agent, were gradually opening space for new social agents linked to the real estate sector and, more recently, in particular from 2016 onwards, articulating actions in collaboration with educational and research institutions and institutions that promote the creative economy.

Recent actions show the relaxation of legislation to favor the action of real estate companies in the urban space of Porto Alegre: in 2019, through the Complementary Law No. 850, the sales index of solo criado ("created land" or license for building rights) of medium-density (between 300 and 1000 $\mathrm{m}^{2} / 3,229.2 \mathrm{ft}^{2}$ and $10,763.9 \mathrm{ft}^{2}$ ) began to be purchased directly at the City Hall. The biggest beneficiaries of this change were the construction companies Melnick Even and Cyrela, which bought the equivalent to $46 \%$ of the value negotiated with the city government, $72 \%$ of the effective and ongoing amount of the solo criado corresponding to Macro-zone 1, where the Floresta and Historic Center neighborhoods are located. In addition, the volumetric regime that falls under the IV District is consistent with the area destined to revitalization and verticalization (AOI-Area of Intensive Occupation) of the 2010 PDDUA, in which the highest heights, between 42 and 52 m (137.9 and $170.7 \mathrm{ft})$, are authorized. From this, it is possible to verify the public sector interest to collaborate with the verticalization and densification process, imperative of the financialized real estate dynamics. Furthermore, the impact of projects subordinate to the real estate and financial market can significantly change the landscape and overload the urban infrastructure already lacking maintenance. Another important highlight are the technology innovation projects, especially with the creation of the group called Pacto Alegre, ${ }^{4}$ in 2019, which coordinates education institutions, government, private initiative, and civil society to stimulate collaborative entrepreneurship, with emphasis on representatives of the leading universities of the state (UFRGS, PUC/RS e Unisinos). These practices reveal the interest for change in the city intended for a specific public. The new suggested meanings occur through agreements between the state, the real estate market, and the business sectors, which open the possibility of productive restructuring, economic conversion, and the inclusion of the area in contemporary 
real estate investment channels of the city, but without great concern for the more vulnerable residents, further distancing them from the city in which they invest and consume.

In response to this broadening of the inequality scenario in the area, the existing problems of social interest housing became more visible. The recent report developed by the Human Rights State Council (CEDH$\mathrm{RS})$, through the Mission in Defense of the Human Right to Housing and Decent Work in Urban Occupations in the Region of the IV District of the City of Porto Alegre/RS (2019), denounces the silent process of expulsion of poor communities from the territory, made possible by vulnerable families' evictions or by the precariousness of the work of wastepickers and recycling warehouses existing in the region.

Observing the actions articulated between the real estate sector and the state (via the city government), we see the recurrent tension of the most impoverished communities, displaced to areas increasingly distant from downtown, in relation to new developments. In the specific case of the area adjacent to downtown Porto Alegre city, motivations for the displacement of lowincome communities are also linked to the insertion of the metropolis and this sector of the city in a local-global development scenario. Given its history as a former industrial sector, it is evident the intentions to update the uses and occupations of the area to demands closer to the current economic interests, through the enhancement of services linked to the creative and technological industry, which are often triggered in cases of economic conversion of former industrial districts.

\section{The profile of housing production in the IV District (2007-2016)}

As seen in the previous item, the improvements made by the Porto Alegre city government, aimed at preparing the city for the 2014 World Cup activities, had among its main beneficiaries the real estate market. Among the companies in the spotlight are the construction companies Rossi Residencial S.A. and, more recently, MRV, which expanded their activities in their cities of origin and, currently, operate in several Brazilian states and the Federal District. ${ }^{5}$ Although the date of entry of the company is after the incorporation initiated by Rossi S.A., it is considered important to mention the contribution of MRV to the real estate dynamics of the area. Especially because it features along with Rossi, and other relevant construction companies in the country that did not operate in Porto Alegre, as great beneficiaries from the cycle of initial public offerings, intensifying their activities and increasing their profits through the sale of housing units of the economic segment.

Concerning the companies' performance in the IV District, we highlight developments located in the Humaitá neighborhood, in the vicinity of Mascarenhas de Moraes park, whose works were initiated around 2010 and there are still some in process of completion in the perimeter. The description of the park appears on the promotion website of the Rossi Flora Condominium, along with details of the apartments and the condo. What to a blind eye might seem just a description of the surroundings turns into domination of 
the public space, aiming to promote private interests, especially when adding the recurring risk of enclosure and privatization of public property. Regarding the real estate products launched in the park vicinity, these are residential condos of two or three bedrooms, with an area between 50 and $70 \mathrm{~m}^{2}$ (538.20 and $753.47 \mathrm{ft}^{2}$ ), whose purchase value varies between $R \$ 250,000$ and $R \$ 450,000$, according to the real estate census prepared by the Union of Civil Construction Industries in the state of Rio Grande do Sul-Sinduscon, between the years 2007 and 2016.

In Graph 1, constructed from collected data and composed of the total numbers of commercial and residential units made available for sale between 2007 and 2016, we can observe that: 1) the Farrapos and Humaitá neighborhoods remained without new products available for purchase in the years 2007, 2009, 2010, and 2011; 2) in 2008, the Humaitá neighborhood presented 105 units; in 2012, 262; and, from 2014, continued offering units until its peak, in 2016, with 195 units; 3) meanwhile, the Farrapos neighborhood remained without offered units until 2013 when it began to present just over 10 units per year. This dynamic shows the Farrapos neighborhood has not become so attractive to the real estate sector, even after the Arena inauguration, in 2012, as opposed to the Humaitá neighborhood, which received a significant number of new housing units in the analyzed years. Still referencing the Farrapos neighborhood, it is worth noting

Graph 1 - Distribution of the number of units offered by neighborhoods-2007/2016

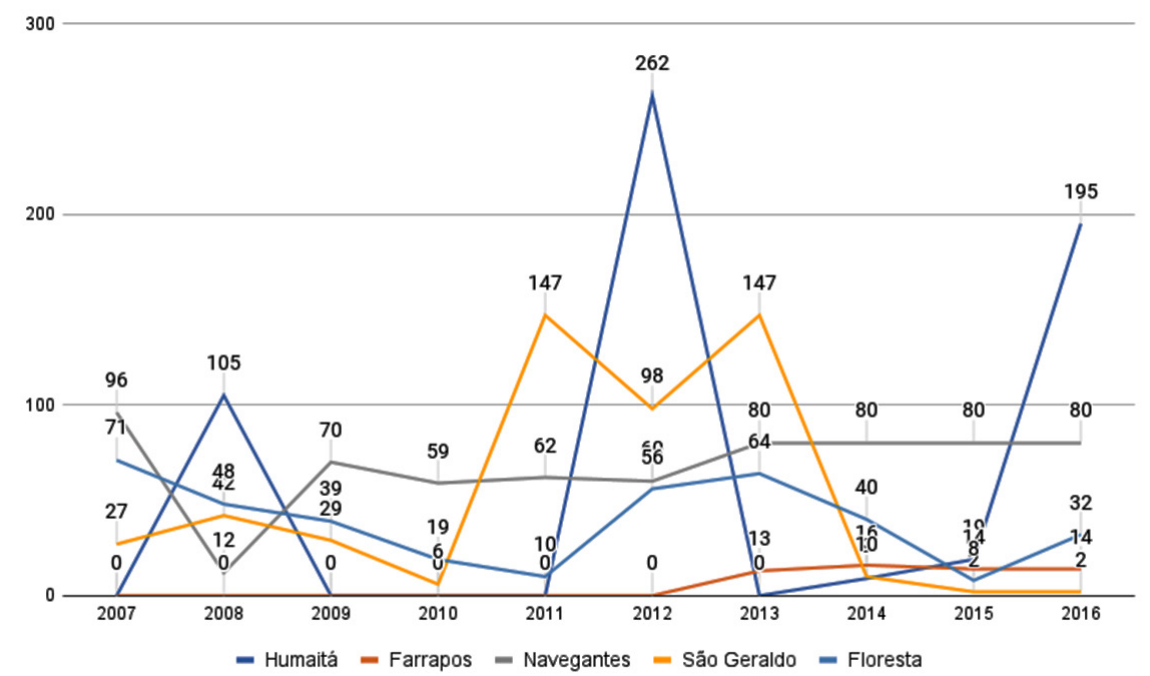

Source: Census of the Real Estate Market of Porto Alegre-Sinduscon/RS, from 2007 to 2016.

Prepared by Nicole Leal de Almeida, in 2021 
the majority of the EHIS built by Piec is located in the neighborhood, in addition to several precarious settlements in undefined situations. With this, we can assume the low incidence of new products may be related to the EHIS areas that have already been regularized and that, for this reason, hinder the removal and decrease the attraction of the market, since it is an area that cannot be incorporated in largescale, but in a fragmented way. Moreover, precarious settlements still existing in the region suffer from frequent tension through judicial measures of property repossession, eviction, and resettlement to areas distant from the place of origin.
It is also observed that, although São Geraldo and Humaitá, according to Graph 1 , are responsible for the highest peaks of real estate availability, in the Navegantes neighborhood there is stability represented by plateaus and results in a number higher than the others of housing units made available. The Floresta neighborhood, in turn, presents a peculiarity compared to the other neighborhoods: $79.84 \%$ of the real estate available for sale, between the years 2007 and 2016, are identified as commercial rooms or shops. Now, in Figure 2, it is verified the affinity between the neighborhoods of the northern end refers to the type of real estate

Figure 2 - Relationship between the residential and commercial units made available between 2007/2016

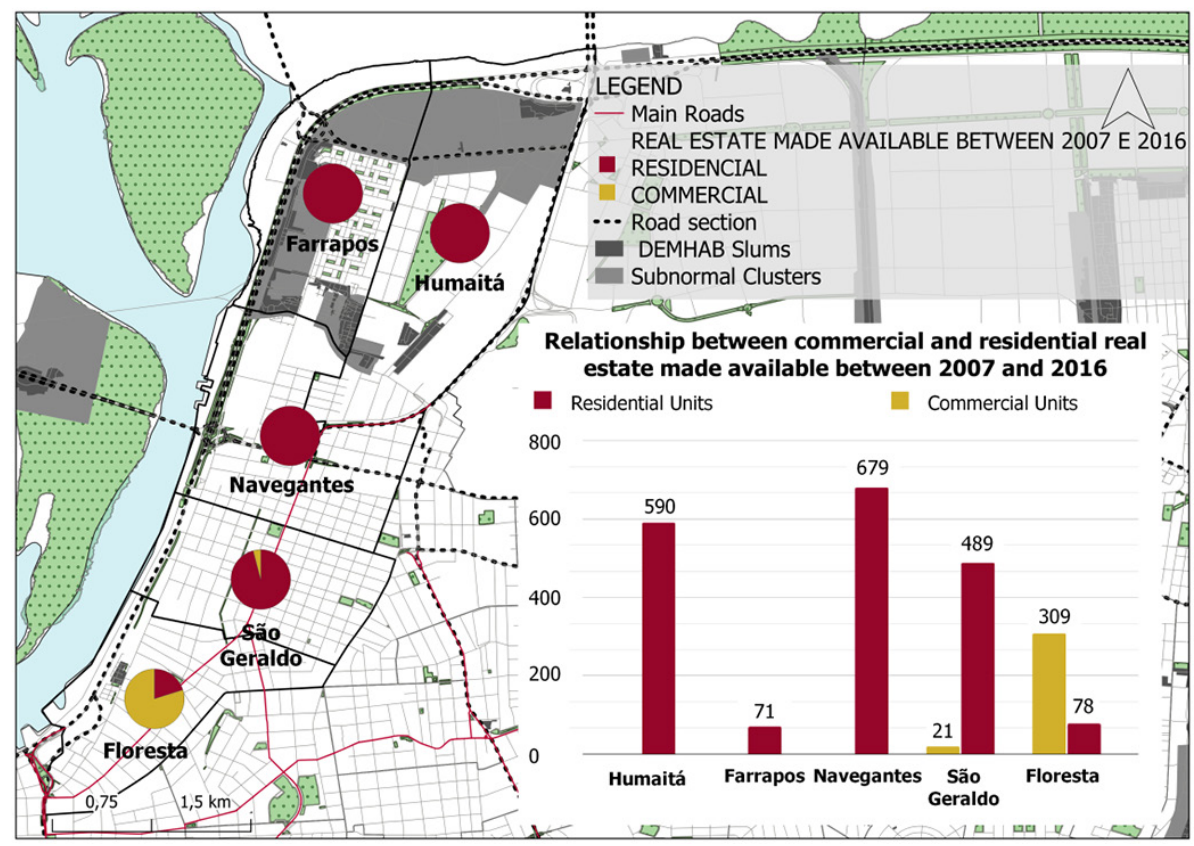

Source: Census of the Real Estate Market of Porto Alegre-Sinduscon/RS, from 2007 to 2016. Prepared by Nicole Leal de Almeida, in 2021. 
available, however, when the total numbers are observed, we confirm the isolation of the Farrapos neighborhood in relation to the others. Regarding the Floresta neighborhood, although the number of housing launches is close to that of the Farrapos neighborhood, the large number of commercial units gives it a distinct characteristic from the others. The distinction presented by the Floresta neighborhood may be related to its proximity to the historic center and to high-income neighborhoods, such as the Moinhos de Vento neighborhood, with which Floresta borders.

When we attribute to the territory data regarding the value of the average nominal income of responsible persons and residents in permanent private households, owned households, and in acquisition (IBGE, 2010), we perceive the contrast between the areas of intensive occupation by real estate developers compared to the precarious settlements and EHIS carried out by Piec. It is possible to verify a great part of the population residing in the surroundings of the development has an average income of two to four MW. ${ }^{6}$ Meanwhile, the gleba that represents the area where the developments are located has an average income of eight MW. Taking as a reference other neighborhoods of Porto Alegre city, the section is compatible, in terms of income, with areas considered noble by the real estate market - Moinhos de Vento, Rio Branco, Petrópolis, Boa Vista, Mont'Serrat, Três Figueiras, and Chácara das Pedras.

Given this, we can say the characterization of the analyzed neighborhoods converges with the argumentation of Shimbo (2010). The author points out the demand for housing met by the economic segment does not correspond to the housing deficit of the country, despite the convenience of confusing social interest housing with "market social housing", in the terms of the author. Still according to Shimbo (ibid.), the Brazilian housing deficit corresponds, for the most part, to the population with a family income of up to three $\mathrm{MW}$, while the population in the range above five MW accounts for a small portion of the deficit. However, it is precisely the range of five MW that presents the greatest shrinkage of the deficit through the economic market follow-up (ibid.). What we can verify in the analyzed spatial cutout, according to the report Mission in Defense of the Human Right to Housing and Decent Work in Urban Occupations in the Region of the IV District of the City of Porto Alegre/RS (2019), organized by the Human Rights State Council$\mathrm{CEDH}$, is that 19 settlements are distributed between the Farrapos neighborhood, in which there is the largest concentration of families, and the Humaitá neighborhood. Figure 3 shows the location of these settlements in the area under analysis.

The settlements are occupied by 1,900 families, who began the occupation 5 years before the publication of the aforementioned Mission report (2019), that is, in 2014. While other settlements have already been in place for at least 30 years, according to the same report. However, this situation shows conditions that indicate negligence on the part of the government, given that many families of these occupations are already registered in housing programs and await definitions on their resettlement. In some cases, families with scarce resources do not invest in improvements in their houses, in general, in a precarious situation, since it is not feasible for the population to invest in spaces from which they will be evicted. In other cases, families 
Figure 3 - Relationship between the average monthly nominal income and the distribution of settlements and Demhab (Municipal Housing Department) slums and the concentrated area of activity of real estate developers

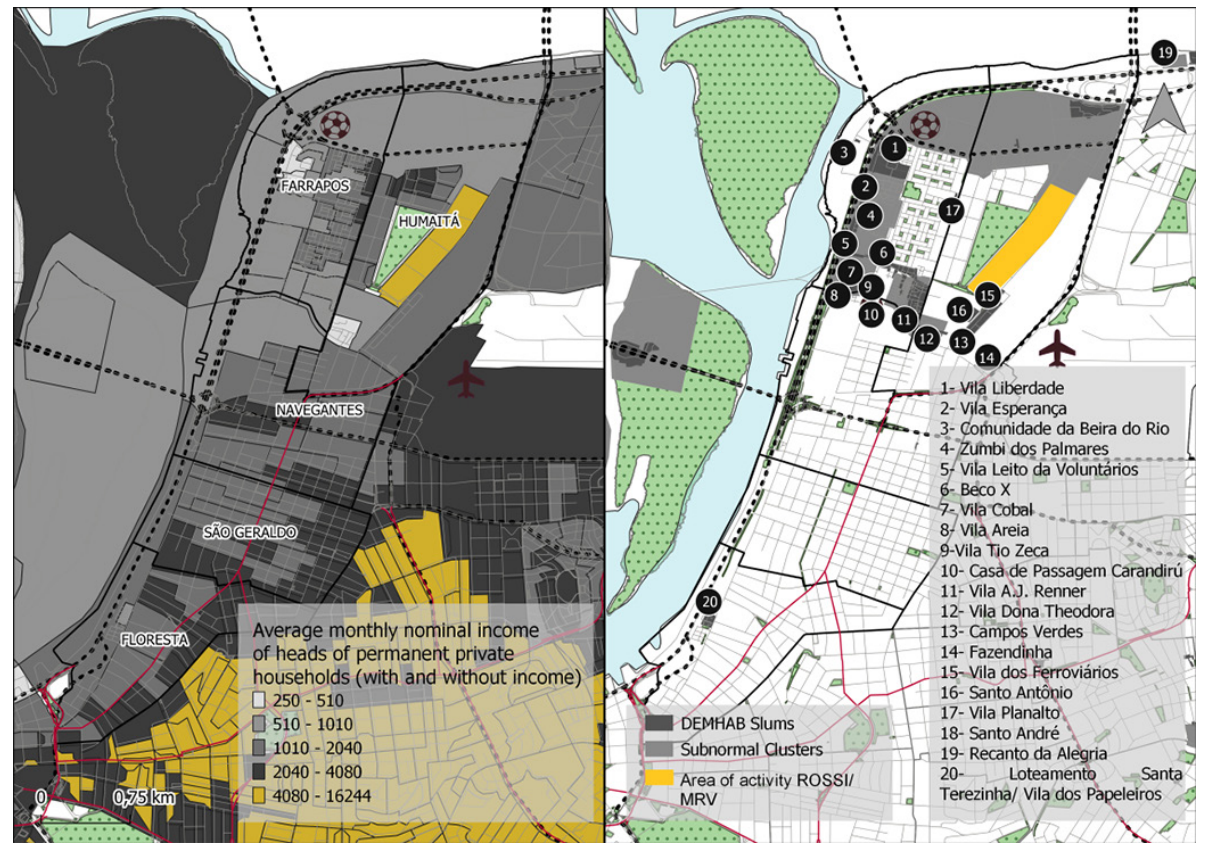

Source: Prepared by Nicole Leal de Almeida, in 2021, from data provided by the Porto Alegre city government (ObservaPOA, s/d).

are under threat of eviction in repossession actions, while occupied areas considered AEIS suffer from spaced investments, many carried out more than 15 years ago. Additionally, the registers made by Demhab are over 20 years old and present significant disparities concerning current demands.

In this sense, it is evident the pressure exerted on vulnerable and impoverished families to move from the IV District, in which there is a negligent action of the state regarding the needs and demands of the poorer social stratum while acting as an enabler for the real estate market activity. Besides the eviction of families, through protective measures of private property and the lack of commitment to the provision of social interest housing, as a fundamental right established in the Federal Constitution (1988), the city government acts on other fronts of tension against the vulnerable population. The current expulsion process also operates on the direct income generation of families via precariousness of work of waste-pickers and recycling warehouses existing in the region, hindering the regularization process of these warehouses and maintaining hygienist and positivist proposals aimed at prohibiting the movement of waste-pickers with drays and pulling carts in the city. 
In the configuration, what is presented are the historical limits of access to infrastructure and decent housing in urban areas upon which the dominance of the commodification of housing production is not imposed. Housing programs, such as My House My Life (2009-2020), end up benefiting the real estate market, which quickly structures itself to meet the open demands. Meanwhile, the most vulnerable strata of the population are not served and are kept on the sidelines, under maintenance of low wages and the neglect of the state. To Rolnik (2019), the very term "subnormal cluster", officially used by the Brazilian Institute of Geography and Statistics (IBGE) to designate precarious settlements, is an indication of the social discrimination institutionalized by the state itself. The author also points out the fate of communities such as these seems to be conditioned to the "destruction-removal-eradication" logic of socalled informal spaces.

On the other hand, neighborhoods that make up the former industrial district of Porto Alegre, and that are closer to the historic center, also undergo a process of transformation in the occupation and use of land. While the Humaitá and Farrapos neighborhoods are marked by explicit conflicts regarding land use, with state intervention with improvements and flexibility to the real estate market aimed at the middle and lower-middle classes, the São Geraldo and Floresta neighborhoods present characteristics closer to economic conversion, through the creative economy market, culture capitalization, and services dedicated to the middle and upper classes.
If, on the one hand, the transformation of the Humaitá and Farrapos neighborhoods' real estate logic occurred after the Arena implementation, sparking a new wave of real estate developments, on the other, it is possible to establish the implementation of the Residential Rossi Fiateci as a milestone in the transformation and resignification of the Navegantes and São Geraldo neighborhoods. The construction of the Residential Rossi Fiateci building announced in 2009, held the promise of being a catalyst for revitalization in Porto Alegre, especially in the São Geraldo neighborhood. The residential building is located where the ruins of one of the most important factories in the region, the Cia. Fiação de Tecidos Porto Alegrense Fiateci, ${ }^{7}$ existed, a business that played a decisive role in the IV District arrangements. Besides employing hundreds of workers and building worker villages in the region, Manoel Py, partner and chairman of the company, accumulated positions in the public and private sectors and was also one of the main shareholders of the Cia Predial e Agrícola (Building and Agricultural Company), according to Strohaecker (2005). In 1902, the real estate development company acquired the Territorial Company of Porto Alegre, which operated mainly in the northern zone of the city, in the Navegantes and São Geraldo neighborhoods. ${ }^{8}$

The mixed-use development, inaugurated in 2012, has four towers, three of them residential, which have names evocative of the link between the investments made in the IV District to well-known restructured spaces in former industrial regions of 
important, globally recognized, metropolises: Soho, Tribeca, and Puerto Madero. By referring the project to the sector in Rio Grande do Sul, it assumes a shape and aesthetic pattern reproduced in several cities around the world and distant from what its context offers. Moreover, these new buildings with old refunctioning strategies, according to Carlos (2015), make up an image of modernization linked to the current neoliberal order, such as the IV District case, becoming targeted for new investments for the amount of vacant land and buildings liable to be incorporated into the real estate market.

However, the availability of areas at low cost is not enough to reclassify sectors of the city, as seen in the case of the Farrapos and Humaitá neighborhoods. The state interference via investments and flexibility of legislation, aside from the national financial and real estate markets' context, was the starting point of the real estate market movement in the region. Carlos (ibid., p. 27) points out the intervention of the state, via local government, is crucial for the hierarchization process of the city sectors", creating new centralities, expelling former residents to the periphery, and recreating a space of dominance"(our translation). In the case of the Navegantes, São Geraldo, and Floresta neighborhoods, the real estate market movement is always mediated by the reorganization of spaces and their traditional meanings.

The resignification of the sector brings as a result the production of new sociability, that is, a new way of appropriating the city through spaces built as consumption desire that can fit into new needs (Padua, 2015). In this sense, the use of old warehouses and big abandoned houses to accommodate breweries, bars, and restaurants can be highlighted. The properties' choice occurs due to the low cost and broad structure, considering their former industrial functions, as well as the potential use of the existing structure as an aesthetic differential, corroborating the statements by Carlos (2015) that the redefinitions of space reflect in social relations as the use and functions of neighborhoods are transformed.

The creative economy is an example of resignification of the area use, other than the housing standards and corporate use. One of the most striking initiatives for the IV District came from the reuse of the Vila Flores architectural complex, designed in 1928 by the architect José Franz Seraph Lutzenberger and, currently, run by the owners, the Wallig family. The opening of the complex to entrepreneurs and artists for creative economy activities is based on four pillars: art and culture, architecture and urbanism, education, and social and creative entrepreneurship. ${ }^{9}$ The association also organizes works collaboratively with other collectives in the region, who fight for better living and working conditions for waste-pickers, and with the settlement 20 de Novembro, in which approximately 40 families occupy the Union building, built to be a hospital and abandoned for more than 50 years. Considering the collaborative actions between the Vila Flores Association and collectives fighting for decent work and housing in the region, it is observed that, although the real estate market has in its favor the hegemony of relations to appropriate independent initiatives, centers of collaborative work with the communities try to strengthen the neighborhoods' autonomy. 
However, Harvey (2014, p. 153) notes that "the better the common qualities that a social group creates, the more likely is they are taken by storm and appropriated by the private interests of profit maximization" (our translation). This is evident in the research by Cardoso (2017), which, through the analysis of articles published in a local newspaper, between 2009 and 2016, observed the construction of a narrative about the IV District that preceded the spatiality of transformations promoted by the creative economy. In the first incursions analyzed by the author, between 2009 and 2013, the creative economy is presented as a possibility for economic growth, corroborated by state actions, technical research, and reports of foreign specialists. In 2012, according to the author, there is the report of the Vila Flores Cultural Association implementation, inaugurated in the same year, as well as the recovery of its architectural complex. These initiatives converge with Arantes' reflection (2013), which highlights the process of urban and heritage revaluation associated with profitability, besides being linked to the architectural and cultural heritage, becoming an ally of the real estate market.

According to Cardoso (2017), it was from 2014 that the insertion of the idea of space recovery via creative economy was verified in journalistic narratives. Between 2014 and 2015, the author identified the concentration of efforts by the analyzed local newspaper to establish an identity linked to the creative economy and justified by the actions of local artists and entrepreneurs. To Molotch (1976), space recovery and growth ideology find support from the local population when they relate growth to the emergence of work.
However, there are no guarantees the local population will benefit, especially considering the construction of the creative identity oblivious to the area residents. Molotch (ibid.) also points out governmental actions play a key role in increasing the growth potential of the area, helping to determine costs and access.

In this logic, to Cardoso (2017), the efforts identified in the construction of the narrative of urban and heritage revaluation were made possible through the proposal of exemption from Tax on Urban Property and Land (IPTU), for five years, for technology-based, innovative, and creative economy companies located in the Floresta, São Geraldo, Navegantes, Humaitá, and Farrapos neighborhoods. This provided the local media identity construction legal validation and corroborated the argument by Molotch (1976). In 2016, Cardoso (2017) considers the spatiality of the IV District is already formed and undergoing a moment of reaffirmation, given the proximity to the municipal elections and the uncertainty regarding public policies for the economic sector, considering the possibility of extinction of the Ministry of Culture and the Secretariat of Creative Economy linked to it. ${ }^{10}$ It is observed, from the systematization drafted by Cardoso (2017), the construction of a narrative aligned to the potentiation of a particular image for the IV District. To Arantes (2013), the use of culture as a tool for identifying individuals and collectivities with the space is associated with "market culturalism". It is understood the homogenization of the several IV District spaces, through an identity built by motivations associated with consumption and the distinction associated with cultural capital, gives the city a commodity status. 
In the wake of the IV District restructuring through its resignification, in 2019 the Secretariat of Culture of Porto Alegre announced the Museum of Contemporary Art/RS would have its own location. The new location is in the Floresta neighborhood, on land donated by the state, a few blocks from the complex that houses Vila Flores, and aims at structuring the territory via interaction between other points of creative culture. The promotion on the museum website highlights intentions with the museum implementation in that sector of the city come from the capacity of the cultural space to "transcend its location" and "be occupied by the community, gradually transforming the IV District itself into a living museum, open to the contemporary manifestations of art, culture, and social action."11

Nevertheless, cultural facilities used as urban intervention could be allied to the social demands of the territory through concrete strategies. Cultural actions that do not promote community autonomy eventually dissolve between the resignification attempts and the approach of agents by taking positions through the accumulation of cultural capital. Since the social space is built in such a way that social agents or groups are distributed according to the principles of differentiation, such as economic and cultural capital, social distances end up reinforcing spatial distances (Bourdieu, 1996). Thus, what is observed is the appropriation of the real estate market in launching products that align with everyday practices legitimized by the capital, while distinguishing and grouping agents that do not act in the space the determined qualities.

\section{Final considerations}

In this article, we discussed the role of the neighborhoods adjacent to downtown as sectors of investment reserve in the city, when undergoing cyclical and longer periods of urban degradation and revaluation through investments made by the state and the real estate capital, the housing policy being an important mechanism of its physical and social transformation. These transformations affect not only the degraded and abandoned spaces but mainly the most vulnerable population that resides there.

According to Carlos (2015), the space transformation of areas adjacent to downtown, as an adaptation of the economic cycles of the city, presents the capacity for renewal of certain sectors of metropolises, a renewal that tends to condition the hierarchization process of the spaces, deepening social and spatial inequalities. Carlos (ibid.) also highlights that, from the conflicts resulting from divergent strategies in the production of space and its permanent transformation, struggles arise showing the setbacks put in the social relations game and in the legitimation of who can occupy the city. From this context, what is presented is the dominance of the neoliberal economy in structures increasingly essential for human life, public and infrastructure services that are being replaced by entrepreneurial practices, which place all individuals as solely responsible for their lives (Butler, 2018).

The analyzed case, IV District of Porto Alegre, encompasses different manifestations of real estate dynamics in the five 
neighborhoods composing it, in a privileged urban location: at the edge of the main metropolitan axis (BR-116 and Trensurb) of city access. Designed for the location of the first industries of Rio Grande do Sul at the end of the 19th century, this was its main function until the end of the first half of the 20th century. The obsolescence and degradation process of the area, as in other situations in Brazilian metropolises, occurred from the 1970s to the mid-1990s, when economic conversion interests began to be built by the government, with the support of the real estate capital and the local media. Currently, the IV District has distinct characteristics that coexist: the low-income population that occupies precarious settlements, urban voids on the land of former industries, and residential real estate developments linked to the Grêmio Arena stadium construction.

This coexistence, not always peaceful, reveals marks of different moments in which several agents participate in the everyday life of the sector, with the clear support of the government allied to the investment interests of the real estate capital. However, throughout the analyses, it becomes evident that, even with the support of the government, areas in a situation of vulnerability did not become interesting to the private sector. As is the case of the Farrapos neighborhood, where the Grêmio Arena and one of the main accesses to the city are located. The reality of vulnerable families located in the area differs greatly from the increasing real estate investments that have taken place or are planned for the majority of neighborhoods that make up the IV District. Precarious settlements in which they live could be taken into account via compensatory measures and mitigations resulting from the construction of new real estate developments and investments. However, such spaces remain susceptible to pressures, directly or indirectly, related to the existing real estate dynamics, along with the urban policy itself developed throughout the history of Porto Alegre.

What is observed is the potentiation of conflicts and constant disputes erupting through measures of property repossession, eviction orders, and resettlement to areas distant from the place of origin. Moreover, the release process of the certificate of occupancy regarding the housing towers already built next to the Arena is underway, which, it is assumed, will bring significant impact to the neighborhood. The analyzed case is revealing as to the participation of state decisions, in its municipal sphere, in the economic and social dynamics of the IV District, since the decisions and laws enabling these transformations of land use and occupation come from the state. The reference present in the area to old models of urban revitalization makes up interventions dissociated, functionally and morphologically, from the reality of its surroundings, breaking with languages and information about a recent past of the city.

At last, it is important to point out that, despite the extensive power of action of the dominant agents, local social movements and cultural groups have been finding ways to resist through insurgent practices and a sense of collectivity. It is these practices, originating from the struggles of the society, that challenge the dominant dynamics and demand attention and studies of their own to contribute so that new arrangements are possible. 


\section{[I] https://orcid.org/0000-0002-9744-3806}

Universidade Federal do Rio Grande do Sul, Faculdade de Arquitetura, Programa de Pós-Graduação em Planejamento Urbano e Regional. Porto Alegre, RS/Brasil.

nlealdealmeida@gmail.com

\section{[II] https://orcid.org/0000-0002-2789-3887}

Universidade Federal do Rio Grande do Sul, Faculdade de Arquitetura, Departamento de Urbanismo, Programa de Pós-Graduação em Planejamento Urbano e Regional. Porto Alegre, RS/Brasil. heleniza.campos@gmail.com

Translation: this article was translated from Portuguese to English by Laura Cristina Gay Reginin, laura.cristina.gay@gmail.com

\section{Notes}

(1) According to Royer (2009, p 73), between 2007 and 2008, the hirings of resources from the SBPE (Housing Finance System) reached their peak and are a result, largely, of the federal government action with the improvement of the regulatory environment and credit for individuals.

(2) The city of Porto Alegre was divided into districts and remained so until 1957 when it began to have as a territorial framework the division by neighborhoods. The aforementioned neighborhoods were a part of the IV District, characterized as the most suitable to host industrial functions.

(3) The city was governed by the following parties: Alceu Collares (PDT, from 1986 to 1988); Olívio Dutra (PT, from 1989 to 1993); Tarso Genro (PT, from 1993 to 1997); Raul Pont (PT, from 1997 to 2001); Tarso Genro and João Verle (PT, from 2001 to 2005); José Fogaça (PPS/PMDB, from 2005 to 2010); José Fortunati (PDT, from 2010 to 2017); Nelson Marchezan Jr. (PSDB, from 2017 to 2021); and, currently, Sebastião Melo (MDB).

(4) See descriptions and projects at: https://pactoalegre.poa.br. Accessed on: March 11, 2021.

(5) According to information from Shimbo (2010), already in the 1990s the company Rossi S.A. identified deficiencies in funding for the economic segment and launched the "Plano 100" and "Vida Nova" aimed at the middle and lower classes. The MRV, in turn, began its operation in the 1970s and focused its activities exclusively on "Empreendimentos Residenciais Populares" ("Popular Residential Developments").

(6) For calculation reference, we considered the minimum wage in force in 2010, the year in which the 2010 census was conducted, which was used as a database. 
(7) The Porto Alegrense Spinning and Weaving Fabric Company was founded on August 6, 1981, in Porto Alegre, by Manoel Py. Information available at: https://fiateci.com.br/. Accessed on: March 11, 2021.

(8) Further information on the activity developments of the allotment companies in the land market of Porto Alegre (1890-1950) are available in Strohaecker (1985 and 2005).

(9) We believe in the power of the connection between people to change the world. Vila Flores. Available at: http://vilaflores.org/. Accessed on: March 11, 2021.

(10) The Ministry of Culture was officially extinguished on January 1, 2019, by Provisional Measure n. 870, published in a special edition of the Diário Oficial da União (Official Gazette).

(11) Our translation; Museum of Contemporary Art RS will have its own location in 2020. Amigos do Macrs. Porto Alegre, 2019. Available at: https://amigosdomacrs.com.br/sede-iv-distrito/ Accessed on: March 24, 2021.

\section{References}

AALBERS, M. (2015). “Corporate Financializations". In: CASTREE, N. et al. (orgs.). The International Encyclopedia of Geography: people, the earth, environment and technology. Oxford, Wiley.

ALBANO, M. T. F. (2015). Quarto Distrito em Porto Alegre: reconhecimento da área e algumas referências. Disponível em: http://Iproweb.procempa.com.br/pmpa/prefpoa/inovapoa/usu_ doc/s8.pdf. Acesso em: 22 fev 2021.

ARANTES, O. (2013). "Uma estratégia fatal: A cultura nas novas gestões urbanas". In: ARANTES, O.; VAINER, C.; MARICATO, E. (orgs.). A cidade do pensamento único: desmanchando consensos. Petrópolis, Vozes.

BOURDIEU, P. (1996). Razões práticas: sobre a teoria da ação. Campinas, Papirus.

BURGESS, E. (1974). "El crecimiento de la ciudad: introducción a un proyecto de investigación". In: THEODORSON, G. A. (coord.). Estudios de Ecologia Humana. Barcelona, Labor, pp. 69-81.

BUTLER. J. (2018). Corpos em aliança e a política das ruas: notas para uma teoria performativa de assembleia. Rio de Janeiro, Civilização Brasileira.

CARDOSO, A. L.; ARAGÃO, T. A. (2011). “A reestruturação do setor imobiliário e o Programa Minha Casa Minha Vida". In: MENDONÇA, J. G; COSTA, H. S. M. (orgs.). Estado e Capital Imobiliário: Convergências atuais na produção do espaço urbano brasileiro. Belo Horizonte, C/Arte.

CARDOSO, R. C. (2017). Espaços criativos: a configuração de uma espacialidade pela narrativa jornalística. Dissertação de mestrado. Porto Alegre, Universidade Federal do Rio Grande do Sul.

CARLOS. A. D. A. (2015). "A reprodução do espaço urbano como momento da acumulação capitalista". In: CARLOS, A. D. A. (org.). Crise urbana. São Paulo, Contexto.

CORRÊA, R. L. (1989). O espaço urbano. São Paulo, Ática. 
FERNANDES, A. C. (2014). Cemitérios industriais: contribuição para a análise espacial da metrópole de Porto Alegre - RS/ Brasil. Tese de doutorado. Porto Alegre, Universidade Federal do Rio Grande do Sul.

FIX, M. A. D. (2011). Financeirização e transformações recentes no circuito imobiliário no Brasil. Tese de doutorado. Campinas, Universidade Estadual de Campinas.

HARVEY, D. (2014). Cidades rebeldes: do direito à cidade à revolução urbana. São Paulo, Martins Fontes.

IBGE - Instituto Brasileiro de Geografia Estatística (2010). Resultados do universo. Disponível em: <https://ftp.ibge.gov.br/Censos/Censo_Demografico_2010/Resultados_do_Universo/Agregados_ por_Setores_Censitarios/RS_20171016.zip> Acesso em: 15 maio 2021.

MATTAR, N. L. (2010). A modernidade de Porto Alegre: arquitetura e espaços urbanos plurifuncionais em área do 4o Distrito. Tese de doutorado. Porto Alegre, Pontifícia Universidade Católica do Rio Grande do Sul.

MIRON, G. I. L. (2008). Gerenciamento dos requisitos dos clientes de empreendimentos habitacionais de interesse social: proposta para o programa integrado entrada da cidade em Porto Alegre/RS. Tese de doutorado. Porto Alegre, Universidade Federal do Rio Grande do Sul.

MOLOTCH, H. (1976). The city as a growth machine: toward a political economy of place. American Journal of Sociology. Published by The University of Chicago Press, v. 82, n. 2, pp. 309-332.

MPRS (2020). Firmado o acordo preliminar para a execução das obras no entorno da Arena. Ministério Público Estado do Rio Grande do Sul. Porto Alegre, 17 nov. Disponível em: https://www.mprs. mp.br/noticias/52319/. Acesso em: 2 mar 2021.

OBSERVAPOA - Observatório da Cidade de Porto Alegre (s/d). Equipamentos e Serviços. Disponível em: < http://observapoa.com.br/default.php?reg=278\&p_secao=46>. Acesso em: 26 maio 2021.

PADUA, R. (2015). “Produção estratégica do espaço e os 'novos produtos imobiliários'”. In: CARLOS, A. F. A; VOLOCHKO, D.; ALVAREZ, I. P. (orgs.). A cidade como negócio. São Paulo, Contexto.

PMPA (2008). Grupo de Trabalho do 4o Distrito. Disponível em: http://www2.portoalegre.rs.gov.br/ spm/default.php?p_secao=150. Acesso em: 22 fev 2021.

(2009). Plano Municipal de Habitação de Interesse Social. Departamento Municipal de Habitação. Porto Alegre. Disponível em: http://lproweb.procempa.com.br/pmpa/prefpoa/ demhab/usu_doc/diagnstico_porto_alegre.pdf Acesso em: 22 fev 2021.

(2011). Plano Diretor de Desenvolvimento Urbano Ambiental de Porto Alegre. Porto Alegre. Disponível em: https://www2.portoalegre.rs.gov.br/spm/default.php?p_secao=205. Acesso em: 22 fev 2021.

ROLNIK, R.; CYMBALISTA, R.; NAKANO, K. (2011). Solo urbano e habitação de interesse social: a questão fundiária na política habitacional e urbana do país. Revista de Direito da ADVOCEF. Brasília, ano VII, n. 13, pp. 123-158.

ROLNIK, R. (2015). Guerra dos lugares: a colonização da terra e da moradia na era das finanças. São Paulo, Boitempo.

(2019). Paisagens para renda, paisagens para vida: disputas contemporâneas pelo território urbano. Revista Indisciplinar. Belo Horizonte, v. 5, n. 1, pp. 18- 43. 
ROYER, L. O. (2009). Financeirização da política habitacional: limites e perspectivas. Tese de doutorado. São Paulo, Universidade de São Paulo.

SHIMBO, L. Z. (2010). Habitação social, habitação de mercado: a confluência entre estado, empresas construtoras e capital financeiro. Tese de doutorado. São Carlos, Universidade de São Paulo.

SINGER, P. (1977). Desenvolvimento econômico e evolução urbana. São Paulo, Companhia Editora Nacional.

(2017). Urbanização e desenvolvimento. Belo Horizonte, Autêntica; São Paulo, Fundação Perseu Abramo.

SOUZA, C. F. DE; MÜLLER, D. M. (1997). Porto Alegre e sua evolução urbana. Porto Alegre, Editora da UFRGS.

STROHAECKER, T. M. (1988). A zona periférica ao centro: uma revisão bibliográfica. Revista Brasileira de Geografia. Rio de Janeiro, ano 50, n. 4. pp. 171-183.

(2005). Atuação do Público e do privado na estruturação do mercado de terras de Porto Alegre (1890-1950). Disponível em: http://www.ub.edu/geocrit/sn/sn-194-13.htm. Acesso em: 22 fev 2021.

TITTON, P. C. (2012). Reestruturação produtiva e regeneração urbana: o caso do IV Distrito de Porto Alegre. Dissertação de mestrado. São Paulo, Universidade Presbiteriana Mackenzie.

Received: March 31, 2021

Approved: June 27, 2021 